\title{
Proofs Of Incorporeality of God In Islam And Judaism: Analysis On The Discourse Of Al-Ghazālī And Maimonides
}

Nurhanisah Senina ${ }^{*}$, Mustafa Kamal Amat Misraa, Khadijah Mohd Khambali @ Hambalib, Wan Adli Wan Ramlib

ajabatan Dakwah Usuluddin, Fakulti Pengajian Peradaban Islam, Kolej Universiti Islam Antarabangsa Selangor

Jabatan Akidah dan Pemikiran Islam, Akademi Pengajian Islam, Universiti Malaya

*Corresponding author: nurbanisab@kuis.edu.my

Article history

Received: 2019-07-08 Received in revised form: 2020-04-07 Accepted: 2020-05-30 Published online: 2021-06-30

\begin{abstract}
This study aims to examine the concept of incorporeality of God according to al-Ghazālī and Maimonides. Due to the existence of 'human-like' attributes and actions in the Hebrew Bible, it entails to various interpretations towards anthropomorphic verses within Muslim and Jewish society. During the golden age of Islamic civilization, fellow Jews and Christian were seen to be engaged in theological discourse with Muslim scholars. The emerging trend during that time in inculcating rational interpretations into religion has triggered scholars to be engaged in the inter-theological dialogue. Prior to this critical situation, alGhazāli and Maimonides were seen playing vital roles in affirming the incorporeality of God and refuting anthropomorphism in their respective religions. Therefore, this study will highlight their methods in affirming the incorporeality of God. In sum, it can be observed that al-Ghazālì employed kaläm's method of arguments on jawhar fard while Maimonides' methods reciprocate Aristotle's argument on the theory of motion. Through their propositions, both scholars denounced God to be associated to any form of substance, accident and body. Both argued that God is an incorporeal being that does not possess any forms or figures. However, Maimonides arguing through the theory of motion led to the concept of God as the First Mover. Meanwhile al-Ghazāli opposed against the former concept and argued that God particularized (mukhasssiss) of every creations. In sum, it is apparent that the argument of incorporeality that serves as the fundamental proposition is essential in having the right understanding on the concept of God. Despite having the similarities in arguing on the incorporeality of God, both al- Ghazâlī and Maimonides differ in comprehending the concept of God.
\end{abstract}

Keywords: Incorporeality of God; al-Ghazäli; Maimonides. 


\subsection{INTRODUCTION}

The discourse of an incorporeal God has always been the fundamental discussion among religious philosophers. The idea of the incorporeality of God is clearly understood within the Abrahamic religions which consists of the three main religions; Judaism, Christianity and Islam. These three religions certainly possess several similarities such as the concept of God, prophets and the hereafter (Wyschogrod, 1982). All the Abrahamic faiths believe that God has sent prophets to teach the people through His revelations. Thus, the notion of an incorporeal God has also been shared commonly among the Abrahamic religions. The understanding of an incorporeal God denotes that God has no physical body or is without any physical substance. However if the incorporeality of God is to be understood as only the denial that God is nonphysical, the idea of trinity must then be excluded from the concept of an incorporeal God. This is due to the incarnation that take form within God the Son who came to be "with body" which is considered as physical substance (Senin, 2016). Whereas in Judaism, the belief of God is one and corporeal is widely professed among the Jews. Although the scripture and Talmud mention various parts of God's physical body such as God's hands, wings and other anthropomorphic terms such as God walking, it must strictly be understood that God possesses no body. Similarly in Islam, Quranic verses inescapably carry anthropomorphic forms of God; such verses are commonly known among Muslim scholars as ayät mutashäbihät (inexplicit verses). Thus these verses if not to be properly understood might leads to the understanding of a corporeal God.

Due to the similar conviction that God is immaterial and must not be associated with any physical body, both Judaism and Islam totally opposed Stoics' idea of a material God and certainly against the idea of a polytheist Gods who worship numbers of God at once. The idea of incorporeality is also against the idea of the pantheism which conceive God as part of the material world.

It was in the Middle Age, due to the socio-geographical assimilation of Jews, Christian and Muslim under the Abbasid Caliphate, theological and philosophical discussions sprouted flourishingly. For Islam, the medieval period did not impose the slightest negative impact of dark ages on its civilization. Muslim scholars such as Ibn Sina, al-Farabi, al-Ghazālī, Ibn Rushd and many others had excelled in their field of knowledge and further attempted to reconcile between reason and revelation particularly within the scholastic period. The emergence of Jewish and Christian philosophy from the Arab philosophy was apparent due to the rapid intellectual advancement of the Arabs during the translation period of Bayt al-ikmab where Greek knowledge was mostly translated to Arabic. Therefore, apart from the language that influenced the writing of the Jews, it is no doubt the Jewish philosophers must have read theological discourse of the Muslim theologians and were influenced with the discourse (Stroumsa, 2009).

It is essential to observe the scenario of the Almohad's reign in Andalus in which Maimonides spent almost twenty years of his life (1148-1165). The Almohad also known as alMuwabhidin (those who proclaim the true unity of God) was a Barbar led caliphate, upheld a strict concept of monotheism and opposed to the concept of anthropomorphism. As a result, Ibn Tumart imposed a force conversion towards Jewish and Christians that led to Maimonides and his family migration to Egypt (Stroumsa, 2009). Undeniably, Maimonides' writings were influenced by the Mu'tazilites and the Muslim peripatetic philosophers namely al-Farabi and Ibn Sina. This can be greatly seen through his reiteration of Aristotelian framework. In addition, Maimonides must have also chanced upon al-Ghazâlī’s writings where similarities can be found in the design of his structure discussions with al-Ghazâlî̀s book Ibyä'(Wolfson, 1979; Harvey, 2001; Pines, 1971; Davidson, 2005; Strauss, 1965). Furthermore, Ibn Tumart was one of al-Ghazālì’s students who 
certainly imposed al-Ghazālî̀s teaching in his reign and without doubt al-Ghazālî̀'s books must have been widely spread. Although Maimonides never mentioned al-Ghazali in his book, it is quite obvious during the reign of Ibn Tumart that he brought in al-Ghazali's writings looking at Ibn Tumart's affiliation with al-Ghazali. Moreover,

Maimonides writings were seen to have some similarities in its phrases structure and theological thinking (Stroumsa, 2009)

Al-Ghazālī and Maimonides were among the prominent Muslim and Jewish middle age thinkers who advanced their proposition within their respective religious discourses. Nevertheless, it can be seen that their tools in arguing God's incorporeality differ as al-Ghazālī employed kalàm argument while Maimonides adopted the philosophical argument reiterating Aristotle's argument. Thus, this study aims to examine and compare the concept of incorporeality according to alGhazālī and Maimonides. Maimonides, also known as Rambam (acronym for Rabbi Moses ben Maimon) embraced philosophy, for he believed that philosophy is readily imbued within the Scriptures. For Maimonides, philosophy was not something alien to religion, as the Scripture itself was revealed in a rational way and man must explore it further (Rudavsky, 2010).

Meanwhile, al-Ghazāli argued that philosophy is not capable of demonstrating the truth. Philosophical tools are not sufficient to penetrate the innermost secret of God, who remains unknown to human understanding -- not because of the insincerity of philosophy, for it too acknowledges the oneness of God, His power and supremacy (Campanini, 2008). Hence, alGhazālī challenged the philosophers' arguments and confronted philosophy with philosophical tools to reveal their incoherence (Watt, 1963).

Therefore, this paper attempts to further discuss the arguments advocated by al-Ghazāli and Maimonides in affirming the incorporeality of God through their methods and the implications in their understanding of His incorporeality.

\subsection{PROOFS OF GOD'S INCORPOREALITY ACCORDING TO AL- GHAZĀLI}

In countering the anthropomorphism of God in Islam, al-Ghazâli initially highlighted the essence of God, which does not constitute a material body, substance, space or any form of accident. AlGhazāli’s argument on incorporeality of God is based on his poofs on the existence of God. This is demonstrated through al-Ghazālī's classification of existence into four different categories. Existence must be either extended (mutahayyiz) or non-extended (ghayr mutahayyiz). Extended existence can be divisible (mutahayyiz, wa i'tiläf) or non-divisible (mutabayyiz wa ghayr i'tiläf). Nonextended existence can be with bodies (ghayr mutahayyiz, bi al-jism) and without bodies (ghayr mutahayyiz, bidūn al-jism) (al-Ghazālī, 2008).

The first two categories apply to extended (mutahayyiz) existence, which requires space. First, existence that occupies space (mutahayyiz) and that can be divisible (i'tiläf) certainly constitutes a body and is known as a body (jism). Secondly, if there is no combination in it or in other terms, non-divisible (ghayr i'tiläf) is known as a single substance (jawhar fard) such as nafs and 'aql. Both require space but are a single substance that does not constitute different parts. Unlike the first, a body constitutes different parts, such as our physical body consisting of multiple limbs (al-Ghazāiti, 2008).

The last two categories refer to non-extended existence (ghayr mutahayyiz), which does not require space to exist. First, non-extended existence that requires bodies for it to exist is known as accident. Al-Ghazālī shunned sophists who disagreed with the theory of accidents, as they claimed 
that knowledge may or may not exist. Accidents are mere possibilities that may or may not exist. On the other hand, the last category denotes non-extended existence that requires neither space nor body to exist and refers to God, Allah (al-Ghazālī, 2008).

From his categorization of existence, it is observed that al-Ghazāli clearly separated God's existence from other existence, for His existence is neither a substance nor a body and certainly not an accident. Body and substance according to al-Ghazâlī can be perceived with the senses. This is not the case with God's existence, as it can only be perceived by proof and not perception. God's existence can only be known through the existence of the universe as a product of His power. This leads to al-Ghazālìss fundamental premise that all existents other than God (bodies or accidents) are temporal, and every temporal being has a cause.

Thus, in understanding the concept of God al-Ghazāli emphasized on affirming that God's essence must be freed from any material body, substance, space or any form of accident as follow.

First, al-Ghazāin affirmed that God's essence should not be a substance that is required to consume space (mutahayyiz); rather, He should be sanctified from any space limitation, as space is inevitably associated with motion and rest. Motion and rest are both temporal and therefore God cannot be associated with space or temporal essence as He is eternal. Moreover, if substance is considered eternal, the universe's substance may also be deemed eternal, which would defeat the notion of God as the only eternal Creator (al-Ghazālī, 2008).

Secondly, al-Ghazālī further denied any bodily figure from God's essence, since a body is composed of different substances. If substances are linked to time, a body certainly expresses temporal essence, something impossible for God. Likewise, substance is inseparable from division, composition, motion, rest, form and quantity, all of which are characteristics of originated phenomena. Besides, the term body must comply with characteristics such as big, small, short and tall, which cannot describe God. His power as the Creator would be limited by designating a body unto Him within our restricted intellectual parameters (al-Ghazālī, 2008).

Next, al-Ghazāli emphasized the absurdity of associating accidents with God. A body is originated and therefore cannot be part of God. If God involves accidents and bodies, He would not be eternal whereas it is impossible for God to have been created. The conclusion is that God is a self-existing being who is free from substance, accidents and bodies that resemble created beings (al-Ghazālī, 2008).

Finally, in affirming God's incorporeality, according to al-Ghazālī one should detach Him from being limited to any direction, because directions can only pertain to created beings that God created with extremities such as left and right. Al-Ghazālī denied directions from God in denying a bodily form of God that may lead one to think God has a figurative nature as humans do. Directions require positing God to a definite place, which is certainly impossible for God. Besides, directions were created by humans, because when God created humans there were no terms indicating directions. If God is said to reside above or below, it may somehow illustrate the existence of a head and legs, referring to a bodily figure (al-Ghazālī, 2008).

According to the propositions above, it can be deduced that al-Ghazāli renounced four basic categories from God's essence, namely space, body, accidents and directions. This is in parallel with his argument that God's existence is not limited to space or body and differs from other existences. Al-Ghazālì's elaboration on this proposition is mentioned in the beginning to demonstrate the importance of adopting a correct understanding of God's essence. 


\subsection{PROOFS OF GOD'S INCORPOREALITY ACCORDING TO MAIMONIDES}

With regards to God's incorporeality, Maimonides strictly denied any form of corporeality of God including apprehending God through anthropomorphic demonstration. Maimonides strongly affirmed that God is unique and there is none like God; God is not a body and has no likeness to others in any way; and each attribute must be understood equivocally (Maimonides, 1963). Maimonides true dedication in affirming that each regular person must be taught a fundamental belief that God is one and incorporeal is apparent in both his texts at the beginning of Mishneh Torah and The Guide. Maimonides' emphasis on the fundamental belief of God according to his Mishneh Torah as well what was uncommon in other Mishneh writing systems, demonstrates his true intention to introduce the significance of this belief system to all Jews.

In Mishneh Torah, Maimonides delivered a fundamental argument in understanding God's unity and incorporeality. He claimed that if deities were plural, it would be necessary for them to be in physical form, since objects can only be distinguished through their material accidents. However, God cannot possess physical form. If He had physical form, God would have limits -which is impossible as God is the most perfect and infinite Being. Thus, He must be one and incorporeal. (Mishneh Torah. http://www.chabad.org/library/article_cdo/aid/682956/jewish/ Mishneh-Torah.htm.)

Meanwhile, in The Guide, it is apparent that Maimonides demonstrated his argument from Aristotle's perspective (Wolfson, 1965). God's incorporeality is demonstrated through the threefold argument of God's existence, unity and incorporeality. He argued the existence of God in conjunction with an agent who sets the spheres in motion by outlining four possibilities of the Agent: either i) corporeality, or ii) incorporeality, or iii) a force distributed throughout all spheres, or iv) an indivisible force from the spheres (Maimonides, 1963).

The first case of corporeality is inadmissible. If the movement agent of the spheres were a corporeal being, it would therefore cause motion to itself in moving the spheres. Hence, an infinite number of agents would be required before the spheres were set in motion. The third argument proposes that a force disseminated throughout all spheres is impossible. If the spheres were corporeal, they would succumb to being finite and motion would be finite, which is against Aristotle's proposition of the perpetuity of motion. The fourth argument is on the indivisibility of force that causes motion to be accidental. Since accidental motion would cause motion to the agent, once it moves accidental motion would be finite -- something not admissible of the agent (Maimonides, 1963).

Hence, Maimonides affirmed the second argument is construed to be the condition of the Prime Mover of the spheres, God. The Cause of the spheres must be incorporeal in order to be eternal and infinite. It must also neither be divisible nor changeable, nor must it experience accidental moves. While it is difficult to positively conceive God's nature, it is logical to know that a first cause must exist. Consequently, through studying the created order, it is possible to gain knowledge on the effect of divine activity. Fulfilling the commandments is a means of developing one's capacities and dispositions, to enable understanding the philosophical truths of the Hebrew Bible (Rudavsky, 2010).

In addition, Maimonides emphasized four necessary elements that should be excluded from God: a) corporeality, b) emotion or change c) non-existence and d) similarity to any creature. He reiterated that non-existence could accidentally occur in one's argument when one does not possess correct understanding of the concept of potential and actual, which is also closely related

Page | 5 
to change. Maimonides advocated that God cannot be affected by changes occurring to transient things nor be associated with potential, for potential indicates His non-existence, therefore rendering created and temporal beings to likewise entail the corporeality of God (Maimonides, 1963). It can be discerned that Maimonides' propositions on God's existence are certainly intertwined with proofs of His incorporeality.

This suggests Maimonides' strong disproof of God's dependence on bodily forms to sustain His existence. God's actions are evidently accomplished by His essence and not by any organs or physical forces connected to organs. Moreover, Maimonides added that the cause of God's will, action and knowledge can only be accomplished with His essence. Thus, regarding belief in God's incorporeality, Maimonides attempted to prove that God is not susceptible to affection, emotion, matter and form.

Maimonides expounded 25 propositions of the philosophers that founded the reasoning behind God's existence and unity. Aristotle was compelled to assume that time and motion are eternal and therefore resulted in the eternity of the universe. Maimonides perceives this to be possible with regard to the propositions of the philosophers (Maimonides, 1963). Nevertheless, it is noted that Maimonides, who was heavily influenced by Aristotle's logic, could no longer ignore his reasoning of cosmological matter. In proving the existence of God, Maimonides first elaborated the argument of His incorporeality. He claimed that the ultimate cause of all genesis and destruction from the motion of the spheres requires an agent to cause the motion. Thus, the mover could neither be corporeally separated from the spheres nor be a force indivisible from the spheres (Maimonides, 1963).

It is obvious that Maimonides refuted Kalam and propositions established by the theologians were pointless to him in his critics against their proofs of God's existence and unity. In contrary, Maimonides opined that philosophical propositions were the best in proving God's incorporeality which is through arguing that God is the First Mover and thus His essence must be excluded from the attachment of bodily forms or accidents. If God is a corporeal First Mover, thus God's essence would have to go through the process of actualization from its potential form and requires another Mover to perform the actualization process. Hence, God must be incorporeal. It is apparent that Maimonides' argument is totally based on the Aristotle's proposition of motion.

\subsection{COMPARATIVE ANALYSIS OF AL-GHAZĀLI AND MAIMONIDES' ARGUMENTS}

It is obvious that both al-Ghazālī and Maimonides' core metaphysical argument emphasize God's incorporeality. Their argument is in response to the presence of anthropomorphic verses in both Scriptures that leads to corporeal understanding of God.

Al-Ghazālī's contention on this subject was presented in several books, principally in Ihya Ulüm al-Din and al-Iqtişäd fi al-I'tiqäd. Meanwhile, Maimonides extensively discussed this matter in both Mishneh Torah and Guide of the Perplexed.

Al-Ghazālī and Maimonides evidently renounced anthropomorphic verses on God's essence. This was to particularly accentuate the belief in God's incorporeality despite the existence of anthropomorphic verses in the Qur'an and the Bible. Both agreed that anthropomorphic verses must not lead to an understanding of a corporeal God. Thus, al-Ghazālī argued that God's essence must be detached from any space, substance, accident or direction. Similar to al-Ghazālī, Maimonides repudiated any form of change from being attributed to God (Senin, 2016). 
Both al-Ghazālī and Maimonides applied demonstrative reasoning to prove God's incorporeality. Al-Ghazālī argued that God's essence must be renounced from space, body, accidents and directions. This directly affirms God's existence but without being attached to space, body or substance. In terms of the origin of existence, every existence must either exist in space or without. Everything that occupies space and is attached to something is known as a body, whereas that which is imbued within is called jawhar fard. As for existence that is not attached to space and is in bodily form is known as accident. On the other hand, existence that is without any attachment to a body or space is God.

Maimonides similarly renounced God's essence to be associated to substance, forms, accidents and body. He explored four possibilities: corporeality, incorporeality, and distributed or indivisible force. He concluded that incorporeality suits God most as the agent and first mover who is not affected by the motion and accidents of other corporeal beings.

It is obvious that al-Ghazâlī's categorization is deduced from the theory of the atom, which is in line with the argument of theologians like the Ash'arite (Dunya, n.d). Meanwhile, Maimonides' categorization that is divided into force and actual, is closely related to the theories of potential and actual as well as emanation of the Aristotle (Senin, 2016).

A substance that inherits a body certainly requires accidents and is subject to temporal creation, which is impossible of God as claimed by al-Ghazālī. Similarly, Maimonides argued that God must neither be corporeal nor reside in a corporeal object that has to be indivisible and unchangeable. The similarity proposes that the Almohad background had an important role in shaping Maimonides' conception of the nature of God, which is contrary to that of the rabbinic position (Senin, 2016).

According to their propositions, al-Ghazālī evidently argued on substance and accidents from the theologians' perspective. On the other hand, Maimonides' argument is parallel to the philosophers especially Aristotle, who reasoned God's incorporeality through the argument of motion.

Al-Ghazālī’s proposition on substance and accidents clearly reiterated al-Juwaynî̀s proposition in affirming the idea of God as the Creator that is opposed to the peripatetic philosophers who advanced the theory of an eternal universe. The theory of eternal universe is strongly refuted by al-Juwayni through his argument on substance (jawhar al-fard) which he argued to be atoms as substance that is indivisible (juг' la yatajaz:a). This argument consequently renounced the idea that a substance is multipliable (al-Juwayni, 1969). According to the mutakallimin, God is the mukhasssis who gives forms to the substance through the merging of accidents with substances that will produce a body (Senin, 2016).

In contrast, the philosophers proposed that substance is multiplied on its own. According to them, all perceived things undergo two states before existing in reality. A thing must first be in a state of potential before it is actualized as real essence. Every substance is readily embedded within it forms of potential which will be actualized to its real essence through God whom is considered as the First Mover who acts as well as the First Intellect that moves the first form which consequently moves other forms. Everything needs an agent to initiate existence. God becomes the mover, as suggested by Aristotle. He moves each matter from its potential state to an actual state (Maimonides, 1963). Maimonides argued in the Aristotelian manner, which deduces that the first mover must not have been inflicted by any motion or change that relates to affections, emotions, matter or forms. Thus, God must be incorporeal. 
Although their arguments somewhat differ in the fundamental proposition of existence, they still acknowledged that God's incorporeality should be held as one of the most essential forms of divinity to be attributed to God. It can be observed that the main divergence between al-Ghazâli and Maimonides is that their arguments stem from different point of discourse. Al-Ghazāli emerged from the argument of jawhar that reiterates the Ashairite's argument which he studied from al-Juwayni. Whereas Maimonides began his argument from the theory of movement that was coined by Aristotle (Senin, 2016).

In conclusion both arguments clearly demonstrated the incorporeality of God. However the implications of both arguments on the subject of His incorporeality led to different conceptions of God. Al-Ghazālī who began his categorization of existence clearly emphasized on the concept of substance which affirmed God as the Creator of universe and the Creator of every events. Meanwhile, Maimonides argued from his argument on the eternity of time and motion which leads to the conception of an incorporeal God who is the First Mover. This is refuted by al-Ghazâli who affirmed that God is the Creator and other substances are created including the universe. Maimonides on the other hand affirmed God as the First Agent who moves forms in its potential state to actual.

Table 1. Comparative Analysis of al-Ghazali and Maimonides on Incorporeality of God

\begin{tabular}{|c|c|c|c|c|}
\hline NO & ISSUE & AL-GHAZĀL $\overline{\mathbf{I}}$ & MAIMONIDES & ANALYSIS \\
\hline 1 & $\begin{array}{l}\text { Incorporeality of } \\
\text { God }\end{array}$ & 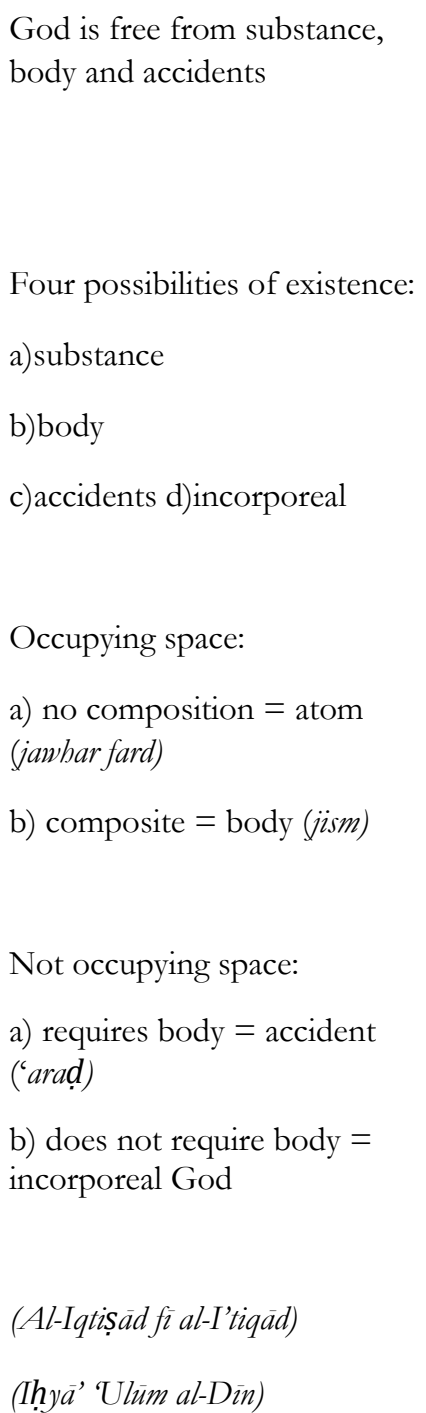 & $\begin{array}{l}\text { God must be free from } \\
\text { substance, accidents and } \\
\text { motion } \\
\text { Four possibilities of } \\
\text { existence: } \\
\text { a)corporeal, } \\
\text { b)incorporeal, } \\
\text { c)distributed force } \\
\text { d)indivisible force } \\
\text { (The Guide of the Perplexed) }\end{array}$ & $\begin{array}{l}\text { Both argued that God is } \\
\text { incorporeal and must be } \\
\text { detached from any form of } \\
\text { substance. } \\
\text { Nevertheless, their } \\
\text { categorization stems from } \\
\text { different argument. Al- } \\
\text { Ghazāli argued from the } \\
\text { premise "Everything except } \\
\text { God is created." } \\
\text { On the other hand, } \\
\text { Maimonides' premise stems } \\
\text { from the argument on } \\
\text { motion which includes the } \\
\text { theory of potential and } \\
\text { actual. }\end{array}$ \\
\hline
\end{tabular}




\subsection{CONCLUSION}

Both thinkers agreed that God is incorporeal which due to their respective religious conviction of a formless and non-physical God. Nevertheless, their argument totally differ as both argued through different proposition. Al-Ghazālì reiterated the Ashairite's proposition in contrast to Aristotelian argument that was employed by Maimonides.

It is apparent that al-Ghazālī who represented kalam scholars during his time adopted the argument of atom in discussing the existence and essence of God. God is considered as the particulariser of each creation. Meanwhile, Maimonides argued that God is the First Mover. This leads to different understanding on the concept of God. Al-Ghazāin believed that God is the necessary existent and He who created the universe. As for Maimonides, he believed God coexisted with the prime matter. Divergence in their arguments is due to their adherence towards different source of propositions. Al-Ghazāli relied upon the Law in perceiving the concept of God where he affirmed that God is the Creator as has been taught in the Quran. Whereas Maimonides believed that philosophy is imbued within the Law which needs can be truly understood through comprehending the philosophical arguments.

\section{References}

Al-Ghazālī, Abu Hamid bin Muhammad (2008). Al-Iqtișād fì al-I'tiqād. Jeddah: Dār al-Minhaj,

Al-Ghazālī, Abu Hamid bin Muhammad (2008). Ihyā̄' Ulüm al-Dìn. Vol. 1. Cairo: Al-Maktabah alTawfiqiyyah,

Al-Juwaynī, Dhiya' al-Din Abd Malik bin Yusuf (1982). Al-Shamil fi Usul al-Din. Iskandariah: Dar al-Maarif

Campanini, Massimo (2008). An Introduction to Islamic Philosophy. Edinburgh: Edinburgh University Press,

Davidson, Herbert (1987). Proofs for Eternity, Creation and the Existence of God in Medieval Islamic and Jewish Philosophy. New York: Oxford University Press,

Harvey, Steven (2005), "Al-Ghazālī and Maimonides and their Books of Knowledge” J.M. Harris (ed.), Be'erot Yitzhak - Studies in Memory of Isadore Twersky

Rudavsky, Tamar (2010). Maimonides. Oxford: Wiley Blackwell,

Stroumsa, Sarah. Maimonides in His World: Portrait of a Mediterranean Thinker. Oxforshire: Princeton University Press, 2009

Sulaiman Dunya (N.d). Al-Haqiqah fì al-Naẓr al-Ghazāli. Cairo: Dār al-Ma‘ārif,

Senin, Nurhanisah (2016). Concept of God in the Discourses of al-Ghazālī (D. 1111) and Maimonides (D.1204). University of Malaya. Unpublished thesis,

Watt, Montgomery (1963). Muslim Intellectual: A study of al-Ghazālī. Edinburgh: Edinburgh University,

Wolfson, Harry Austryn (1965). Maimonides in the Unity and Incorporeality of God. The Jewish Quaterly Review. 56 (2), 112-136

Wolfson, Harry Austryn (1979). Repercussion of the Kalam in Jewish Philosophy. USA: Harvard University Press

Wyschogrod, Michael (1982). Trialogue of the Abrahamic Faiths. USA: International Studies Group of Academy of Religion, 